\title{
Pengembangan Sediaan Emulgel Antioksidan dan Tabir Surya Mengandung Ekstrak Kulit Buah Cokelat
} (Theobroma cacao L)

\section{The Development of Antioxidant and Sunscreen Emulgel Containing Cocoa Pod Husk Extract (Theobroma cacao L)}

Sani Ega Priani*, Rizki Anggara Permana, Mira Nurseha, Ratih Aryani

Program Studi Farmasi, Fakultas MIPA, Universitas Islam Bandung, Bandung, Indonesia

*Corresponding author: sani.ega.p@unisba.ac.id

Submitted: 6 February 2021

Accepted: 26 August 2021

Published: 30 November 2021

\begin{abstract}
Background: Cocoa pod husk is a waste chocolate processing that has not been widely used. Previous research has shown that cocoa pod husk contains polyphenol and flavonoid compounds so the it potential to have antioxidant and photoprotective activities. Objective: The study was conducted to determine the antioxidant and sunscreen activities of the cocoa pod husk extract and to develop the extract into an emulgel with good physical properties and stability. Methods: The extraction process was conducted by maceration using $70 \%$ ethanol. The antioxidant activity test was performed using the DPPH (1,1-diphenyl-2-picryl-hydrazyl) method and the sunscreen activity test was conducted using the spectrophotometric-based Mansur method. Emulgel preparations are made using olive oil as the oil phase, sodium lauryl sulfate and ceto stearyl alcohol as the surfactant, and viscolam mac 10 as the gelling agent. Results: The results showed that the cocoa pod husk extract has a very strong antioxidant activity indicated by an IC $C_{50}$ value of $16.74 \pm 0.72$ ppm and also had sunscreen activity with an SPF value of $10.78 \pm 0.85$ (1000 ppm). The emulgel preparation with $2 \%$ of extract has good physical characteristics based on organoleptic, pH, homogeneity, spreadability, viscosity, and rheology tests. The preparation was also stable based on freeze-thaw and centrifugation tests. Conclusion: The cocoa pod husk extract showed very strong antioxidant activity and also has sunscreen activity. It can be developed into an emulgel preparation with good physical characteristics and stability.
\end{abstract}

Keywords: cocoa pod husk, sunscreen, antioxidant, emulgel

\begin{abstract}
Abstrak
Pendahuluan: Kulit buah cokelat merupakan limbah hasil pengolahan cokelat yang belum banyak dimanfaatkan. Penelitian sebelumnya menunjukkan bahwa kulit buah cokelat mengandung banyak senyawa polifenol dan flavonoid sehingga berpotensi memiliki aktivitas antioksidan dan pelindung surya. Tujuan: untuk menguji potensi aktivitas antioksidan dan fotoprotektif dari ekstrak etanol kulit buah cokelat secara in vitro dan juga untuk mengembangkan ekstrak menjadi sediaan emulgel yang memiliki karakteristik fisik dan stabilitas yang memenuhi persyaratan. Metode: Proses ekstraksi dari limbah kulit buah cokelat dilakukan dengan metode maserasi menggunakan etanol 70\%. Uji aktivitas antioksidan dari ekstrak kulit buah cokelat dilakukan dengan metode DPPH sedangkan uji aktivitas pelindung surya dilakukan dengan metode Mansur berbasis spektrofotometri. Sediaan emulgel dikembangkan dengan minyak zaitun sebagai fasa minyak, natrium lauril sufat dan setostearil alkohol sebagan surfaktan, dan viscolam mac 10 sebagai gelling agent. Hasil: Ekstrak etanol 70\% dari kulit buah cokelat terbukti memiliki aktivitas antioksidan sangat kuat yang ditandai dengan nilai $\mathrm{IC}_{50} 16,74 \pm 0,72 \mathrm{ppm}$. Ekstrak juga berpotensi sebagai agen fotoprotektif karena memiliki kemampuan pelindung surya nilai SPF 10,78 $\pm 0,85$ (1000 ppm). Sediaan emulgel dengan ekstrak kulit buah cokelat $2 \%$ yang dihasilkan memiliki sifat fisik yang baik didasarkan pada hasil pengujian organoleptis, homogenitas, $\mathrm{pH}$, daya sebar, viskositas, dan sifat alir. Sediaan emulgel juga stabil didasarkan pada hasil uji sentrifugasi dan freeze thaw. Kesimpulan: Ekstrak etanol
\end{abstract}


dari kulit buah cokelat diketahui memiliki aktivitas antioksidan sangat kuat dan juga aktivitas pelindung surya serta dapat dikembangkan menjadi sediaan emulgel yang memiliki karakteristik fisik yang sesuai.

Kata kunci: limbah kulit buah cokelat, antioksidan, tabir surya, emulgel

\section{PENDAHULUAN}

Paparan sinar matahari memiliki implikasi kesehatan yang penting dan diperlukan untuk fungsi fisiologis tubuh. Akan tetapi, paparan radiasi sinar ultraviolet (UV) berlebih diketahui dapat menyebabkan berbagai efek negatif pada kulit seperti munculnya pigmentasi, eritema, penurunan elastisitas kulit, imunosupresi, penuaan dini, hingga dapat menjadi salah satu pemicu terjadinya kanker kulit (Utami dkk., 2016). Efek negatif atau berbahaya dari radiasi matahari umumnya terjadi karena adanya spektrum elektromagnetik sinar ultraviolet A/UV A (320 $400 \mathrm{~nm})$ dan UV B (290 - $320 \mathrm{~nm}$ ) (Savoye dkk., 2018). Efek negatif dari sinar UV, terjadi karena kemampuannya untuk menginduksi spesies oksigen reaktif atau sering disebut dengan istilah Reactive Oxigen Species (ROS). Terbentuknya ROS dapat memicu terjadinya stress oksidatif, terutama bila antioksidan alami tubuh tidak berhasil meredam kondisi tersebut (Pizzino dkk., 2017). Kondisi stress oksidatif dapat menyebabkan kerusakan sel (misalnya peroksidasi lipid dan fragmentasi DNA), apoptosis, dan kematian sel (Baek \& Lee, 2016).

Untuk mencegah efek negatif dari paparan berlebihan dari sinar UV, setidaknya bisa dilakukan dengan dua cara (Widyastuti dkk., 2016). Cara yang pertama dengan penggunakan agen fotoprotektif dalam bentuk sediaan tabir surya yang mampu melindungi kulit dengan cara memantulkan atau menyerap sinar UV. Cara yang kedua dapat dilakukan dengan menggunakan senyawa antioksidan yang dapat meredam efek negatif dari pembentukan ROS akibat induksi sinar UV (Lin dkk., 2019).

Berbagai tanaman diketahui menghasilkan senyawa aktif yang mampu meredam efek buruk paparan berlebihan sinar UV. Senyawa polifenol dan flavonoid diketahui memiliki aktivitas antioksidan untuk meredam efek negatif ROS. Selain itu senyawa-senyawa tersebut diketahui mampu memberikan perlindungan terhadap kulit, dengan beraksi sebagai tabir surya kimia (chemical sunscreen) yang memiliki kemampuan untuk menyerap radiasi sinar UV (Huyut dkk., 2017; José dkk., 2016).

Salah satu bahan yang berasal dari alam yang diketahui mengandung senyawa fenolik yang tinggi adalah kulit buah cokelat. Kulit buah cokelat adalah limbah yang dihasilkan pada proses pengolahan buah cokelat. Bagian kulit buahnya bisa mencapai $75 \%$ dari total buah. Saat ini limbah tersebut belum banyak dimanfaatkan di bidang kesehatan dan kosmetika (Ouattara dkk., 2020; Utami dkk., 2016). Seiring dengan tingginya tingkat produksi cokelat di Indonesia, maka jumlah limbah kulit buah cokelat juga semakin meningkat. Penelitian yang telah dilakukan sebelumnya, menunjukkan bahwa ekstrak etanol kulit buah cokelat dari perkebunan di Ciamis, Jawa Barat, memiliki kadar polifenol sebesar 15,56\% atau 155,6 mg GAE/g (Priani dkk., 2019). Penelitian lainnya menunjukkan bahwa ekstrak kulit buah cokelat mengandung senyawa flavonoid sebesar $22,42+0,98 \mathrm{mg}$ rutin ekivalen/g (Abdul dkk., 2014).

Untuk meningkatkan kenyamanan dan efektifitas pemakaian, kulit buah cokelat dikembangkan menjadi sediaan emulgel (Kumar dkk., 2016). Emulgel adalah salah satu jenis sediaan semisolida yang merupakan kombinasi sistem emulsi dan gel. Dibandingkan dengan sistem emulsi (krim) sediaan emulgel memiliki keuntungan diantaranya adalah stabilitas sistem emulsi yang meningkat karena peningkatkan viskositas fase air sebagai fase luar dengan keberadaan gelling agent. Sediaan emulgel juga diketahui mampu melekat lebih baik dibandingkan dengan sediaan krim, sehingga sesuai diaplikasikan untuk sediaan tabir surya (Sreevidya, 2019). Dibandingkan dengan sediaan gel, keuntungan dari sistem emulgel adalah mampu memfasilitasi penghantaran senyawa yang bersifat hidrofil dan hidrofob karena emulgel merupakan sistem dua fase minyak dan air (Mohite dkk., 2019).

Tujuan dari penelitian ini adalah untuk menguji aktivitas antioksidan dan pelindung surya (fotoprotektif) dari ekstrak etanol $70 \%$ kulit buah cokelat secara in vitro. Ekstrak kulit buah cokelat selanjutnya dikembangkan menjadi sediaan emulgel yang memiliki karakteristik fisik yang baik dengan aktivitas sebagai antioksidan dan tabir surya.

\section{BAHAN DAN METODE Bahan}

Bahan utama pada penelitian ini adalah limbah kulit buah cokelat yang diperoleh dari perkebunan cokelat di 
Ciamis, Jawa Barat pada Desember 2018. Selain itu juga digunakan etanol 70\% (bratachem), DPPH (sigmaaldrich), minyak zaitun (Lansida), propilenglikol (Bratachem), viscolam Mac 10 (Lamberty Spa), natrium lauril sulfat, setostearil alkohol, dan trietanolamin (TEA).

\section{Alat}

Alat dan instrumen yang digunakan pada studi ini adalah hot plate (Cimarec, Thermo Scientific), timbangan analitik (Metler Toledo AL 204), rotary evaporator (Buchi), ultraturax (IKA T25, digital), stirrer (IKA RW 20, digital), viscometer Brookfield (DV-I Prime), dan spektrofotometer UV-Vis (Shimadzu-UV mini-1240).

\section{Metode}

\section{Penyiapan ekstrak kulit buah cokelat}

Limbah kulit buah cokelat dikeringkan pada suhu $40-50^{\circ} \mathrm{C}$ menggunakan lemari pengering hingga mencapai kadar air simplisia $<10 \%$ (pada penelitian ini kadar air simplisia kering 8\%). Simplisia kering selanjutnya diserbukkan dan diekstraksi menggunakan etanol $70 \%$ pada perbandingan pelarut $1: 3$ dengan tiga kali pengulangan, masing-masing 24 jam. Ekstrak cair selanjutnya dikeringkan dengan vacuum rotary evaporator sampai diperoleh ekstrak kental, dan selanjutnya dipekatkan dengan waterbath. Terhadap ekstrak selanjutnya dilakukan penapisan fitokimia menggunakan prosedur pengujian baku (Rachmawaty dkk., 2018).

\section{Uji aktivitas antioksidan ekstrak kulit buah cokelat}

Uji aktivitas antioksidan dilakukan dengan metode DPPH. Dibuat satu seri larutan ekstrak dalam etanol p.a pada seri konsentrasi ekstrak 25, 20, 15, 10, dan 5 ppm. Larutan ekstrak ditambahkan larutan DPPH $60 \mathrm{ppm}$ (dalam etanol p.a) dengan perbandingan $1: 1$. Campuran diaduk menggunakan vortex selama 1 menit dan selanjutnya diinkubasi 30 menit pada suhu ruangan. Terhadap sampel selanjutnya dilakukan analisis dengan spektrofotometer UV- Vis. Nilai absorbansi dari sampel diukur pada panjang gelombang maksimum dari DPPH yang sudah ditentukan sebelumnya yaitu $517 \mathrm{~nm}$, untuk mendapatkan nilai absorbansi uji. Untuk perhitungan \% inhibisi, dilakukan juga pengukuran absorbansi larutan DPPH dengan penambahan etanol $1: 1$ tanpa penambahan ekstrak (Abs DPPH) setelah inkubasi 30 menit. Nilai \% inhibisi senyawa uji dihitung melalui rumus sebagai berikut (1) (Priani dkk., 2020):

$$
\% \text { Inhibisi }=\left(\frac{\text { Abs DPPH }- \text { Abs Uji }}{\text { Abs DPPH }}\right) \times 100 \%
$$

Nilai konsentrasi hambat $50 \%$ atau $\mathrm{IC}_{50}$ diperoleh dengan membuat kurva $\%$ inhibisi terhadap konsentrasi ekstrak. $\mathrm{IC}_{50}$ adalah nilai konsentrasi ekstrak yang memberikan hambatan DPPH sebanyak 50\% (Islam dkk., 2020).

Uji aktivitas tabir surya ekstrak kulit buah cokelat

Dibuat larutan ekstrak dalam etanol pada konsentrasi ekstrak 1000 ppm. Selanjutnya dilakukan pengukuran absorbansi pada rentang panjang gelombang 290 - $320 \mathrm{~nm}$ pada setiap interval $5 \mathrm{~nm}$. Nilai Sun Protection Factor (SPF) dihitung dengan persamaan Mansur (2) (Abdassah dkk., 2015):

$$
\mathrm{SPF}=\mathrm{CF} \times \sum_{290}^{320} \operatorname{EE}(\lambda) \times \mathrm{I}(\lambda) \mathrm{x} \operatorname{Abs}(\lambda)
$$

Keterangan:

$\mathrm{EE}=$ spectrum yang menyebabkan eritema $\mathrm{I}=$ intensitas spectrum

Abs $=$ Absorbansi

$\mathrm{CF}=$ faktor koreksi (10)

\section{Formulasi sediaan emulgel kulit buah cokelat}

Sediaan emulgel dibuat berdasarkan formula emulgel yang sudah dikembangkan sebelumnya namun dengan modifikasi jenis gelling agent yang digunakan, yakni viscolam Mac-10 (Tabel 1).

Tabel 1. Formulasi sediaan emulgel kulit buah cokelat

\begin{tabular}{cc}
\hline Bahan & Kadar $(\%)$ \\
\hline Ekstrak & 2 \\
Minyak zaitun & 20 \\
Natrium lauril sulfat & 0,5 \\
Setostearil alkohol & 4,5 \\
Viscolam Mac 10 & 5 \\
TEA & $\mathrm{qs}$ \\
Metil paraben & 0,02 \\
Propil paraben & 0,18 \\
Tokoferol & 0,03 \\
Propilenglikol & 15 \\
Aquadest ad & 100 \\
\hline
\end{tabular}

Sediaan dibuat dengan memanaskan fase minyak (minyak zaitun dalam setostearil alkohol) dan fase air (natrium lauril sulfat dalam aquadest) sampai suhu $60^{\circ} \mathrm{C}$ - $70^{\circ} \mathrm{C}$. Selanjutnya kedua fase dicampur dan diaduk pada kecepatan $4000 \mathrm{rpm}$ menggunakan high speed homogenizer (ultra turrax), selama 15 menit hingga terbentuk masa emulsi. Ke dalam campuran ditambahkan ekstrak, tokoferol, propil paraben, dan metil paraben, yang sudah dilarutkan dalam propilenglikol. Lakukan pengadukan kembali dengan menggunakan high speed homogenizer selama 15 menit dengan kecepatan $4.000 \mathrm{rpm}$. Selanjutnya viscolam ditambahkan ke dalam campuran dan dilakukan netralisasi dengan penambahan TEA sedikit demi 
sedikit hingga $\mathrm{pH}$ sediaan mencapai $6-7$. Terakhir sediaan dihomogenkan menggunakan stirrer pada kecepatan 300 rpm selama 15 menit untuk membentuk sistem emulgel (Sabri dkk., 2016).

\section{Evaluasi fisik sediaan emulgel kulit buah cokelat}

Sediaan diuji sifat fisiknya meliputi organoleptis, homogenitas, $\mathrm{pH}$, viskositas, sifat alir, dan daya sebar. (Priani dkk., 2019)

\section{Organoleptis dan homogenitas}

Uji organoleptis dilakukan dengan melakukan pengamatan terhadap penampilan fisik sediaan emulgel kulit buah cokelat secara visual sedangkan homogenitas dilakukan dengan mengoleskan sediaan emulgel pada kaca preparat selanjutnya ditempatkan preparat kaca lainnya di atasnya, dan diamati keberadaan partikel kasar pada sediaan.

\section{Uji pH}

pH sediaan emulgel kulit buah cokelat ditentukan dengan menggunakan $\mathrm{pH}$ meter yang telah dikalibrasi.

\section{Uji daya sebar berukuran}

$0,5 \mathrm{~g}$ sediaan diletakkan di selembar kaca berukuran $20 \times 20 \mathrm{~cm}$ dan selanjutnya di atasnya diletakkan kaca lain dan dibiarkan selama 1 menit. Setelahnya ditambahkan beban 50 gram dan sistem selanjutnya didiamkan selama 1 menit kemudian diukur diameternya hingga konstan (Tambunan \& Sulaiman, 2018).

\section{Uji viskositas dan sifat alir}

Pengujian viskositas dan sifat alir dari sediaan emulgel yang umumnya merupakan sistem non newton, dilakukan dengan menggunakan viscometer Brookfield (DV-1 Prime). Viskositas diukur pada kecepatan $100 \mathrm{rpm}$. Untuk menentukan sifat alir viskositas sediaan dilakukan pengukuran viskositas pada berbagai nilai rpm yakni 10, 20, 50, dan 100 rpm. Kemudian dilakukan sebaliknya 100, 5020 dan 10 rpm untuk melihat apakah sifat alir dari sediaan emulgel termasuk kategori sifat alir dipengaruhi waktu atau tidak (Berdey \& Voyt, 2016).

\section{Uji stabilitas sediaan emulgel kulit buah cokelat}

Uji stabilitas dilakukan dengan uji sentrifugasi dan freeze thaw (Hamsinah dkk., 2016).

\section{Uji sentrifugasi}

Sediaan emulgel disentrifuga pada kecepatan putar 3800 rpm selama 5 jam. Kemudian diamati ada tidaknya pemisahan fase (Hamsinah dkk., 2016).

\section{Uji freeze thaw}

Sediaan emulgel ditempatkan pada suhu $4^{\circ} \mathrm{C}$ selama minimal 24 jam kemudian dipindahkan suhu $40^{\circ} \mathrm{C}$ selama minimal 24 jam (1 siklus). Uji dilakukan selama 6 siklus. Kemudain diamati ada tidaknya pemisahan fase (Hamsinah dkk., 2016).

\section{HASIL DAN PEMBAHASAN}

Limbah kulit buah cokelat yang diketahui mengandung senyawa polifenol dan flavonoid akan dikembangkan menjadi sediaan kosmetika alami. Untuk menarik kandungan senyawa di dalamnya dilakukan proses ekstraksi dengan metode maserasi menggunakan etanol $70 \%$. Pemilihan metode maserasi dilakukan untuk mempertahankan stabilitas dari senyawa-senyawa aktif dan penggunaan pelarut etanol $70 \%$ didasarkan penelitian sebelumnya yang diketahui mampu menghasilkan rendemen ekstrak yang lebih baik (Rachmawaty dkk., 2018). Ekstrak yang diperoleh selanjutnya dilakukan penapisan fitokimia dan hasilnya diketahui bahwa ekstrak etanol kulit buah cokelat mengandung senyawa alkaloid, tannin, flavonoid, kuinon, polifenol, saponin, terpenoid, monoterpen dan seskuiterpen. Senyawa metabolit sekunder tersebut seperti flavonoid dan polifenol yang pada akhirnya akan mendukung aktivitas dari ekstrak.

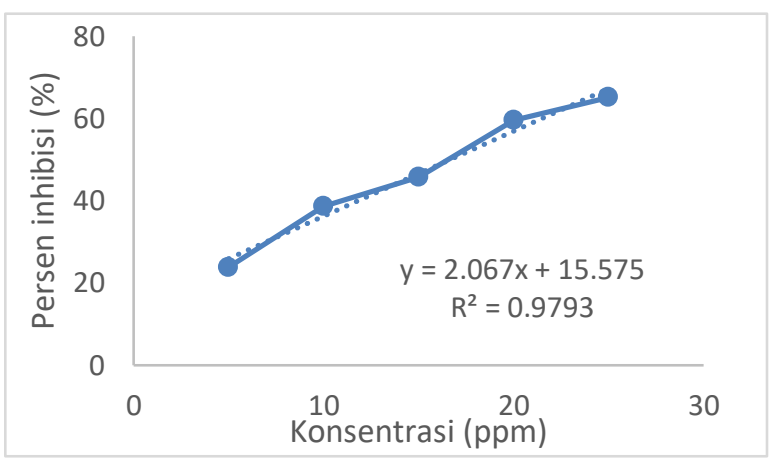

Gambar 1. Kurva uji aktivitas antioksidan ekstrak

Uji aktivitas aktioksidan ekstrak kulit buah cokelat dilakukan dengan metode DPPH. Hasil pengujian menunjukkan bahwa ekstrak yang dihasilkan, memiliki aktivitas antioksidan yang sangat kuat, yang ditandai dengan nilai $\mathrm{IC}_{50} 16,74 \pm 0,72 \mathrm{ppm}$ (<50 ppm) (Gambar 1). Aktivitas antioksidan dari kulit buah cokelat diketahui muncul karena adanya senyawa fenolat seperti asam fenolat, flavonoid, juga senyawa polifenol lainnya. Adanya asam sitrat dan asam malat dalam kulit buah cokelat juga diketahui mendukung aktivitas antioksidannya. Pada penelitian lainnya yang juga melakukan uji aktivitas antioksidan pada ekstrak kulit buah cokelat namun menggunakan pelarut pengekstrak yang berbeda yakni etanol $80 \%$ memberikan hasil nilai $\mathrm{IC}_{50} 26,1 \mathrm{ppm}$, yang juga tergolong ke dalam aktivitas antioksidan sangat kuat (Abdul dkk., 2014). Adanya sedikit perbedaan pada nilai $\mathrm{IC}_{50}$ dapat dimungkinkan karena perbedaan jenis pelarut yang digunakan, yang bisa berpengaruh pada polaritas dan juga jenis serta jumlah seenyawa bioaktif yang terekstrak. 
Selanjutnya terhadap ekstrak dilakukan uji aktivitas pelindung surya. Pengujian dilakukan secara in vitro dengan melihat absorbansi sampel pada panjang gelombang sinar UV B yang diwakili dengan pengukuran absorbansi menggunakan spektrofotometer UV pada panjang gelombang $290-320 \mathrm{~nm}$. Pengujian ini sesuai untuk menguji bahan/sediaan tabir surya kimia (chemical sunscreen). Tabir surya kimia melindungi tubuh dari efek negatif sinar UV dengan cara menyerap radiasi yang sampai ke permukaan kulit (Adamson \& Shinkai, 2020). Tabir surya kimia umumnya merupakan senyawa aromatik yang terkonjugasi dengan gugus karbonil. Struktur ini memungkinkan molekul untuk menyerap sinar UV berenergi tinggi dan melepaskan sebagai sinar berenergi lebih rendah, sehingga mencegah sinar UV merusak DNA atau sel kulit (Geoffrey dkk., 2019). Senyawa bahan alam seperti golongan flavonoid dapat memberikan efek tersebut, karena gugus aromatik yang dimilikinya. Senyawa flavonoid memiliki struktur dasar yang terdiri dari dua gugus aromatik yang dihubungkan oleh adanya jembatan karbon membentuk struktur C6C3-C6 (Panche dkk., 2016).

Hasil uji aktivitas tabir surya menunjukkan bahwa pada konsentrasi yang diujikan, ekstrak etanol kulit buah cokelat memiliki nilai SPF $10,78 \pm 0,85$, dengan data perhitungan diperlihatkan pada Tabel 2. Hasil tersebut termasuk kategori perlindungan maksimum (konsentrasi $1000 \mathrm{ppm}$ ) karena memiliki nilai SPF pada rentang 8 - 15 (Geraldine \& Hastuti, 2018). Penjelasan tentang nilai $\mathrm{EE}, \mathrm{I}, \mathrm{Abs}$, dan $\mathrm{CF}$ bisa dilihat di persamaan (2).

Tabel 2. Hasil pengujian tabir surya ekstrak kulit buah cokelat

\begin{tabular}{cccc}
\hline $\begin{array}{c}\text { Panjang } \\
\text { gelombang }\end{array}$ & EExI & $\begin{array}{c}\text { Absorbansi* } \\
\text { (rata-rata) }\end{array}$ & EExIxAxCF \\
\hline 290 & 0,015 & 1,87 & 0,28 \\
295 & 0,081 & 1,31 & 1,06 \\
300 & 0,287 & 1,08 & 3,09 \\
305 & 0,372 & 1,00 & 3,70 \\
310 & 0,186 & 0,94 & 1,75 \\
315 & 0,083 & 0,91 & 0,75 \\
320 & 0,018 & 0,88 & 0,16 \\
\hline \multicolumn{4}{c}{ Total (Nilai SPF) } \\
\hline
\end{tabular}

Setelah terbukti bahwa ekstrak kulit buah cokelat potensial untuk dikembangkan menjadi sediaan kosmetika karena memiliki efek antioksidan dan tabir surya, maka dilanjutkan dengan pengembangan ekstrak menjadi sediaan emulgel. Pemilihan sediaan emulgel didasarkan pada stabilitasnya yang lebih baik dibandingkan dengan sediaan krim karena peningkatan viskositas fase luar (fase air) oleh adanya gelling agent. P-ISSN: 2406-9388

E-ISSN: 2580-8303
Selain itu sediaan emulgel diketahui mampu menghasilkan daya lekat yang lebih baik akibat penambahan gelling agent sehingga lebih sesuai untuk sediaan tabir surya. Sediaan emulgel juga bisa memfasilitasi penghantaran senyawa hidrofil dan hidrofob seperti yang terdapat pada ekstrak kulit buah cokelat yang masih merupakan sistem multi komponen (Sah dkk., 2017). Selanjutnya terhadap sediaan emulgel, ditambahkan ekstrak kulit buah cokelat sebagai zat aktif pada konsentrasi $2 \%$. Nilai ini ditingkatkan dari nilai $\mathrm{IC}_{50}$ antioksidan ekstrak. Peningkatan kadar bahan aktif dalam sediaan dari nilai $\mathrm{IC}_{50}$ nya umum dilakukan termasuk untuk senyawa aktif kimia seperti alfa tokoferol dan asam askorbat, denga tujuan untuk meningkatkan efektifitasnya (Aryani, 2015).

Untuk formula basis emulgel yang digunakan merujuk pada formula yang sudah dikembangkan sebelumnya, yang diketahui menghasilkan karakteristik sediaan yang baik dan stabil (Priani dkk., 2014). Modifikasi dilakukan pada gelling agent yang digunakan yakni viscolam mac 10. Penggunaan viscolam memiliki beberapa keuntungan yakni bentuknya yang cair sehingga mempermudah pencampuran dan juga dapat berfungsi sebagai pelembab kulit atau emollient sehingga memberikan nilai tambah untuk penghantaran topikal (Luliana dkk., 2019). Hasil evaluasi sediaan emulgel ditampilkan pada Tabel 3.

Tabel 3. Hasil evaluasi sediaan emulgel

\begin{tabular}{cc}
\hline Parameter & Hasil \\
\hline Organoleptis & $\begin{array}{c}\text { semisolida, tidak berbau, } \\
\text { berwarna kecoklatan }\end{array}$ \\
Homogenitas & Homogen \\
pH & $7,05 \pm 0,02$ \\
Daya sebar & $3,06 \pm 0,12 \mathrm{~cm}$ \\
Viskositas (100 rpm) & $29493 \pm 907 \mathrm{cps}$ \\
Sifat alir & Pseudoplastis \\
Uji sentrifuga (5 jam) & Stabil \\
Uji freeze thaw & Stabil \\
\hline
\end{tabular}

Dari hasil tersebut, terlihat bahwa sediaan memiliki karakteristik yang baik, ditandai dengan nilai $\mathrm{pH}$ sesuai dengan batas $\mathrm{pH}$ sediaan topikal $(4,5-7)$, nilai daya sebar sesuai untuk sediaan semisolida (3 - 7), dengan sifat alir pseudoplastis (Garg dkk., 2002). Sifat alir pseudoplastis sesuai untuk pemakaian topikal, dimana ketika sediaan dioleskan akan terjadi penurunan viskositas sehingga mempermudah penyebarannya (Berdey \& Voyt, 2016).

Berdasarkan hasil uji stabilitas diketahui bahwa sediaan memiliki stabilitas yang baik yang ditandai 
dengan tidak adanya creaming ataupun pemisahan fase pada uji sentrifugasi ataupun freeze thaw. Hal tersebut menggambarkan bahwa sediaan dapat mempertahankan stabilitasnya akibat pengaruh gaya gravitasi ataupun pengaruh perubahan suhu (Mustarichie \& Gozali, 2019).

\section{KESIMPULAN}

Hasil penelitian menunjukkan ekstrak etanol $70 \%$ dari kulit buah cokelat memiliki aktivitas antioksidan sangat kuat yang ditandai dengan nilai $\mathrm{IC}_{50} 16,74 \pm 0,72$ ppm dan juga memiliki aktivitas pelindung surya dengan nilai SPF $10,78 \pm 0,85$, pada konsentrasi ekstrak $1000 \mathrm{ppm}$. Ekstrak etanol kulit buah cokelat telah berhasil dikembangkan menjadi sediaan emulgel dengan sifat fisik yang baik berdasarkan pengujian organoleptis, homogenitas, daya sebar, $\mathrm{pH}$, viskositas, dan sifat alir. Sediaan emulgel ekstrak kulit buah cokelat juga stabil berdasarkan uji sentrifugasi dan freeze thaw.

\section{UCAPAN TERIMA KASIH}

Ucapan terima kasih disampaikan kepada LPPM UNISBA atas hibah penelitian dosen utama yang diberikan sehingga proses penelitian ini dapat terlaksana dengan baik.

\section{DAFTAR PUSTAKA}

Abdassah, M., Aryani, R., Surachman, E. \& Muchtaridi, M. (2015). In-Vitro Assessment of Effectiveness and Photostability Avobenzone in Cream Formulations by Combination Ethyl Ascorbic Acid and Alpha Tocopherol Acetate. Journal of Applied Pharmaceutical Science; 5; 70-74.

Abdul, K. A., Azlan, A., Ismail, A., Hashim, P., Abd, G. S. S., Zainudin, B. H. \& Abdullah, N. A. (2014). Phenolic Composition, Antioxidant, AntiWrinkles and Tyrosinase Inhibitory Activities of Cocoa Pod Extract. BMC Complementary and Alternative Medicine; 14; 1-113.

Adamson, A. S. \& Shinkai K. (2020) Systemic Absorption of Sunscreen: Balancing Benefits with Unknown Harms. JAMA; 323; 223-224.

Aryani, R. (2015). Formulasi Dan Uji Stabilitas Krim Kombinasi Alfa Tokoferol Asetat dan Etil Vitamin C Sebagai Pelembab Kulit. Jurnal Kesehatan Bakti Tunas Husada; 14; 38-45.

Baek, J. \& Lee, M. G. (2016). Oxidative Stress and Antioxidant Strategies in Dermatology. Redox Report; 21; 164-169.

Berdey, I. I. \& Voyt, O. I. (2016). Rheological Properties of Emulgel Formulations Based on
Different Gelling Agent. The Pharma Innovation Journal TPI; 5; 76-79.

Garg, A., Aggarwal, D., Garg, S. \& Singla, A. K. (2002). Spreading of Semisolid Formulations: An update. Pharmaceutical Technology North America; 26; 84-105.

Geoffrey, K., Mwangi, A. N. \& Maru, S. M. (2019). Sunscreen Products: Rationale for Use, Formulation Development and Regulatory Considerations. Saudi Pharmaceutical Journal; 27; 1009-1018.

Geraldine, E. T. \& Hastuti, E. D. (2018). Formulation of Sunscreen Cream of Parijoto Fruit Extract (Medinilla speciosa blume) and In Vitro Spf Value Test. Journal of Pharmaceutical Sciences and Community; 15; 92-98.

Hamsinah, H., Darijanto, S. D. \& Mauluddin, R. (2016). Uji Stabilitas Formulasi Krim Tabir Surya Serbuk Rumput Laut (Eucheuma cottonii doty). Jurnal Fitofarmaka Indonesia; 3; 155-160.

Huyut, Z., Beydemir, Ş. \& Gülçin, I. (2017). Antioxidant and Antiradical Properties of Selected Flavonoids and Phenolic Compounds. Biochemistry Research International; 2017; 1-8.

Islam, M. Z., Cho, D. K. \& Lee, Y. T. (2020). Bioactive Compounds and Antioxidant Capacity of Tea Infusion Prepared from Whole And Ground Medicinal Herb Parts. CYTA - Journal of Food; 18 3003-3011.

José, M. T. de A. F., Pedrita, A. S., Emanuella, C. V. P., Raimundo, G. de O. J., Fabrício, S. S., Jackson, R. G. da S. A., Larissa, A. R., Xirley, P. N. \& Edigênia, C. da C. A. (2016). Flavonoids as Photoprotective Agents: A Systematic Review. Journal of Medicinal Plants Research; 10; 848864.

Kumar, D., Singh, J., Antil, M. \& Kumar, V. (2016). Emulgel-Novel Topical Drug Delivery System - A Comprehensive Review. International Journal of Pharmaceutical Sciences and Research; 7; 473342.

Lin, Q., Xu Xu, R. H. J., Yang, N., Karim, A. A., Loh, X. J. \& Zhang, K. (2019). UV Protection and Antioxidant Activity of Nanodiamonds and Fullerenes for Sunscreen Formulations. ACS Applied Nano Materials; 2; 7604-7616.

Luliana, S., Desnita, R. \& Mufliha, U. (2019). The Influence of Menthol in Ethanol Extract of Meniran Gel (Phyllanthus niruri L.) as a Hair Growth Promoter in Male Wistar Rats. Majalah Obat Tradisional; 24; 1-8. 
Mohite, S. V., Salunkhe, A. K. \& Sudke, S. G. (2019). Emulgel: A Novel Approach for Hydrophobic Drugs. American Journal of PharmTech Research; 7; 43-60.

Mustarichie, R. \& Gozali, D. (2019). Formulation and Evaluation of Alpha Arbutin Skin Lightening Cream Using Polyacrylate Base by Cold Process. International Journal of Applied Pharmaceutics; $11 ; 100-105$.

Ouattara, L. Y., Kouassi, E. K. A., Soro, D., Soro, Y., Yao, K. B., Adouby, K., Drogui, A. P., Tyagi, D. R. \& Aina, P. M. (2020). Cocoa Pod Husks as Potential Sources of Renewable High-ValueAdded Products: A Review of Current Valorizations and Future Prospects. Bioresources; 16; 1988-2020.

Panche, A. N., Diwan, A. D. \& Chandra, S. R. (2016). Flavonoids: An Overview. Journal of Nutritional Science; 5; 1-15.

Pizzino, G., Irrera, N., Cucinotta, M., Pallio, G., Mannino, F., Arcoraci, V., Squadrito, F., Altavilla, D. \& Bitto, A. (2017). Oxidative Stress: Harms and Benefits for Human Health. Oxidative Medicine and Cellular Longevity; 2017; 1-13.

Priani, S. E., Aprilia, S., Aryani, R. \& Purwanti, L. (2019). Antioxidant and Tyrosinase Inhibitory Activity of Face Serum Containing Cocoa Pod Husk Phytosome (Theobroma cacao L.). Journal of Applied Pharmaceutical Science; 9; 110-115.

Priani, S. E., Humanisya, H. \& Darusman, F. (2014). Development of Sunscreen Emulgel Containing Cinnamomum Burmannii Stem Bark Extract. International Journal of Science and Research; 3; 2338-2341.

Priani, S. E., Lestari, I. A., \& Lestari, F. (2019). Pengembangan Sediaan Emulgel Mengandung Minyak Biji Anggur (Vitis vinifera L.) dan Uji Aktvitas Antiluka Terhadap Tikus Wistar Jantan (Rattus norvegicus). Jurnal Ilmiah Ibnu Sina (JIIS): Ilmu Farmasi dan Kesehatan; 4; 66-76.

Priani, S. E., Mutiara, R. M. \& Mulyanti, D. (2020). The Development of Antioxidant Peel-Off Facial
Masks from Cinnamon Bark Extract (Cinnamomum burmannii). Pharmaciana; 10; 6976.

Rachmawaty, Mu'Nisa, A., Hasri, Pagarra, H., Hartati, \& Maulana, Z. (2018). Active Compounds Extraction of Cocoa Pod Husk (Thebroma cacao 1.) and Potential as Fungicides. Journal of Physics: Conference Series; 1028; 1-8.

Sabri, H. S., Ali, W. K., Abdullah, B. H. \& Al-Ani, W. M. K. (2016). Formulation Design and Evaluation of Anti-Microbial Activity of Emulgel Containing Essential Oil of Myrtus communis L. International Journal of Pharmaceutical Sciences Review and Research; 40; 271-277

Sah, S. K., Badola, A. \& Nayak, B. K. (2017). Emulgel: Magnifying the Application of Topical Drug Delivery. Indian Journal of Pharmaceutical and Biological Research; 5; 25-33.

Savoye, I., Olsen, C. M., Whiteman, D. C., Bijon, A., Wald, L., Dartois, L., Clavel-Chapelon, F., Boutron-Ruault, M. C. \& Kvaskoff, M. (2018). Patterns of Ultraviolet Radiation Exposure and Skin Cancer Risk: the E3N-SunExp Study. Journal of Epidemiology; 28; 27-33.

Sreevidya, V. S. (2019). An Overview on Emulgel. International Journal of Pharmaceutical and Phytopharmacological Research; 9; 92-97.

Tambunan, S. \& Sulaiman, T. N. S. (2018). Formulasi Gel Minyak Atsiri Sereh dengan Basis HPMC dan Karbopol. Majalah Farmaseutik; 14; 87-95

Utami, R. R., Armunanto, R., Rahardjo, S., \& Supriyanto. (2016). Effects of cocoa bean (Theobroma cacao L.) Fermentation on Phenolic Content, Antioxidant Activity and Functional Group of Cocoa Bean Shell. Pakistan Journal of Nutrition; 15; 948-952.

Widyastuti, W., Kusuma, A. E., Nurlaili, N. \& Sukmawati, F. (2016). Antioxidant and Sunscreen Activities of Ethanol Extract of Strawberry Leaves (Fragaria x ananassa A.N. Duchesne). Jurnal Sains Farmasi \& Klinis; 3; 19-24. 